\title{
Review
}

\section{The Madness of George III by Alan Bennett (National Theatre)}

\author{
Hugh Freeman, Editor, The British Journal of Psychiatry
}

The mighty in a fallen state represent one of the oldest themes in drama, reminding people in each successive epoch that underneath the trappings of power and authority is but a mortal man - or sometimes woman. Alan Bennett's depiction of The Madness of George III follows a trajectory from 'Before' - royal business, marital contentment, and family conflict - through the agonies of psychosis and its medical responses, to 'After' - (more or less) back to normal.

George III was not the first English King to go mad and was certainly not the only one of contem porary monarchs to do so, but his is the first case for which we have detailed evidence. Every registrar knows (as Macaulay might have said) that the cause was porphyria, and that this was revealed by Macalpine \& Hunter in their classic work of 1969 conveniently reissued now in paperback. The King's illness was not only constitutionally significant (Freeman, 1991), but undoubtedly helped to bring the care of mental illness in Britain out of the barbaric depths portrayed by Hogarth and others. In this, it resonated with influences such as the opening of The Retreat at York, a few years before the event depicted in this play.

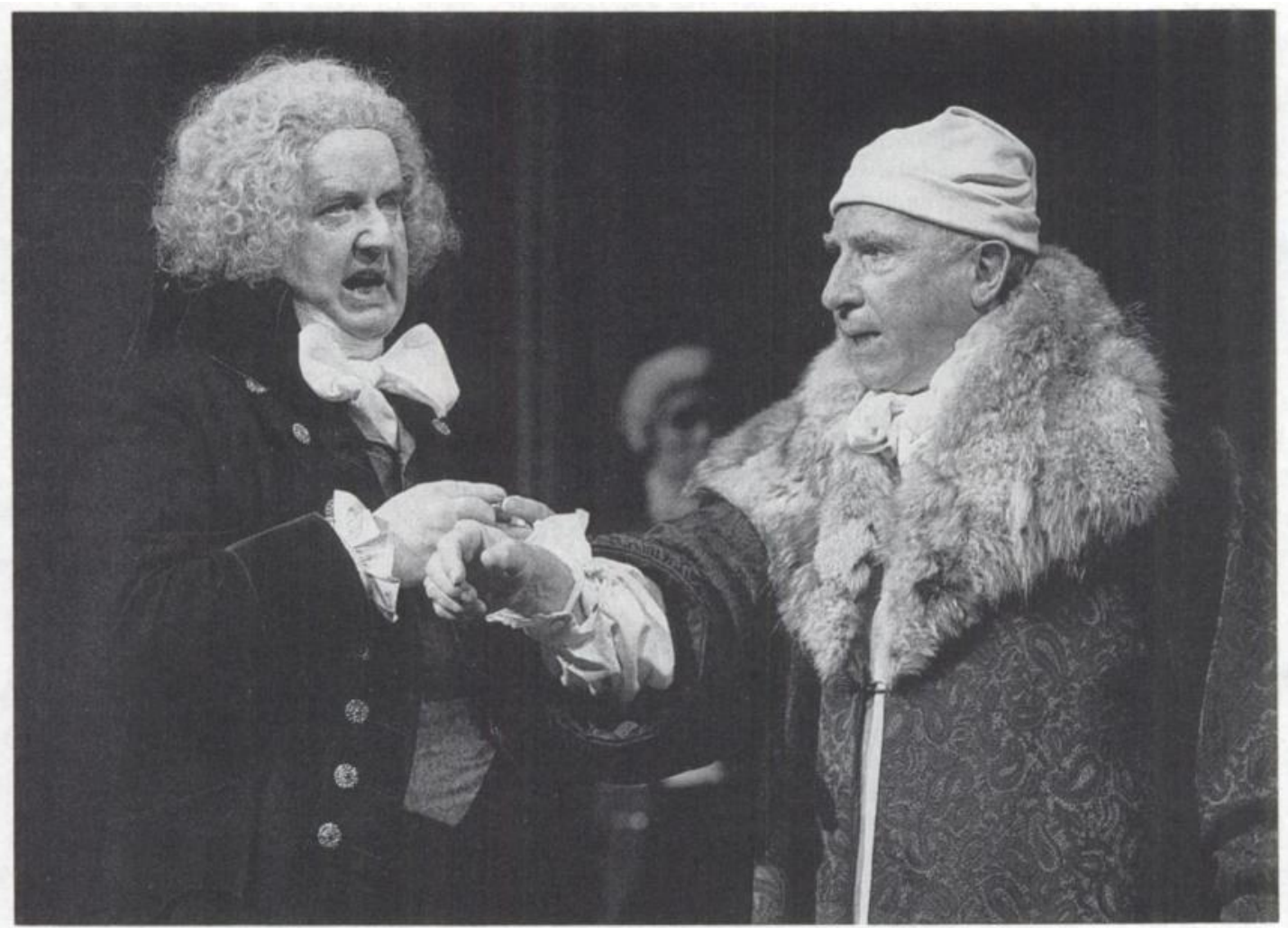

Left to right: Harold Innocent (Sir George Baker) and Nigel Hawthorne (George III). (Photograph by Donald Cooper). 
Because the King was sovereign - still then in a very real sense - any incapacity on his part had enormous political significance. Bennett shows that as Prime Minister, Pitt depended on the Royal prerogative to continue the flow of honours, salaries, and perks that kept a Parliamentary majority intact: he and the King were locked in a state of mutual dependence. Meanwhile, the Opposition gave its allegiance to the Prince of Wales - 'the reversion'; in an unreformed House of Commons, there was nothing else they could do.

This play skilfully mingles such political manoeuvrings with the clinical ups and downs of the King that they reflected. Pitt does his utmost to conceal the illness, as an earlier one was successfully hushed up, and when this is no longer possible, conveys opitimistic bulletins that become increasingly unconvincing. The Prince of Wales contributes the services of his personal physician, Dr Warren, who has strong motivations for making sure that no recovery occurs. Meanwhile, the Lord Chancellor plays both sides of the field, agilely returning to Pitt's camp when he sees some evidence of Royal improvement, while the Prince and his brother, impatient to get their hands on the levers of patronage, see these almost within their grasp, but finally snatched away by the King's recovery.

Psychiatrists will be particularly interested in the portrayal of the King's illness and how it was treated. On the whole, this is impeccable - from the first suspicions that the King's actions are more than an enhancement of his usual habits, through signs of frank psychosis to restituo ad integrum. The blundering attentions of the Royal physicians - a trio out of Molière and Rowlandson, with echoes of The Doctor's Dilemma - are, regrettably, just as accurate. There is, though, one real historical weakness, and this concerns Dr Willis. Seen here as a naive rural clergyman with a line in Skinnerian conditioning, he was in fact a much more formidable figure: as Roy Porter points out in his programme note, Willis' encounter at a Parliamentary Committee with a sceptical Edmund Burke left that normally dominant figure thoroughly worsted. In the prevailing state of knowledge, Willis' management of the King was probably the most effective available.

There is also some conceptual muddle in the play's conclusion. Clad (with much dramatic licence) in a white hospital coat, "Ida Macalpine" declares that the King was "not mad, but suffering from porphyria". In fact, he was certainly mad, but his psychotic state had an understandable organic cause. In this, the play reflects a misunderstanding that has taken root among non-medical historians, and which has similarities to the Laingian doctrines that were so influential on dramatists of the 1970s. The fact that an abnormal mental state has an understandable cause (or what is believed to be an understandable cause) doesn't in fact make it any less abnormal. Cultural history is full of the portrayal of madness as 'a metaphor of the human condition', but as Kevin Jackson pointed out (1991), "To write as though madness were vision, liberation and truth is either callow or callous ... mental illness is not metaphor; it is an illness".

Nevertheless, in the mature phase of his career, Alan Bennett has scaled one height after another, and this is surely his finest work so far. The play has absorbing tension, intense pathos, and humour sprinkled with almost Wildean one-liners. As George III, Nigel Hawthorne is not only dramatically superb, but bears an uncanny resemblance to contemporary portraits of the King. The production is spectacular and gripping, only let down at times by some rather reach-me-down scenery.

At the end of the play's first part, the theatre fills with the sound of Handel's coronation anthem, Zadok the Priest. Simultaneously, we see a tormented king, bound to his chair by a strap which has ironic echoes of the Garter sash that had been an essential part of his earlier apparel; even the restraining chair itself poignantly recalls the shape of the one in which he was crowned. The play ends with the King' arrival at St Paul's for thanksgiving on his recovery. We can momentarily share in this pleasure, though at the same time uneasily aware that he will again fall victim to that genetic Bad Fairy of porphyria.

\section{References}

Freeman, H. L. (1991) The brain and political behaviour. British Journal of Psychiatry, 159, 19-32.

JACKSON, I. (1991) The Independent. November 27.

MACAlPINE, I. \& HUNTER, R. (1969) George III and The Mad Business. London: Allen Lane. 